Journal of Southeast Asian Studies, 38(2), pp 293-308 June 2007. Printed in the United Kingdom.

(C) 2007 The National University of Singapore doi:10.1017/S0022463407000057

\title{
A Commissioner calls: Alexander Paterson and colonial Burma's prisons
}

\author{
lan Brown
}

In 1925, Alexander Paterson, a Commissioner for Prisons in England and Wales, arrived in Rangoon to advise the local government on gaol conditions in Burma. This paper explores why the Burma prison administration invited Paterson, examines his findings and proposals - that included the suggestion that no convict should spend more than two years in gaol - and considers the fate of his recommendations. Paterson's visit and views are set in the social and political contexts of British rule in Burma at that time.

In November 1925, Alexander Paterson, a Commissioner for Prisons in England and Wales, arrived in Rangoon, having accepted an invitation from the local government 'to advise generally on Jail conditions in Burma, as well as on the possibility of introducing a modified form of the Borstal System'. 'Paterson was a considerable catch for what was, after all, merely a province of British India. Not only was he a very senior figure in the home prison administration - at any one time there was a maximum of just five prison commissioners, responsible for the prison system throughout England and Wales - but also, by all accounts, a man of great presence and ideas.

When an undergraduate in the mid-1900s, Paterson had been drawn to the settlement movement that had grown out of the teaching of T. H. Green at Oxford University in the late 1870s, in which students and graduates went to live in urban slums, working voluntarily in education and welfare centres - or 'settlements'. During university vacations he worked in the Oxford Medical Mission to Bermondsey, a desperately deprived inner-London borough on the south bank of the river. Moreover

Ian Brown is Professor of the Economic History of South East Asia at the School of Oriental and African Studies, London. Correspondence in connection with this paper should be addressed to ib@soas.ac.uk. Research for this paper was made possible by generous financial support from the Arts and Humanities Research Council for a major project, 'Cultures of confinement: the history of the prison in Asia, Africa, and Latin America', based in the History Department of the School of Oriental and African Studies, London. I wish to thank Thet Thet Wintin, the research assistant on the project, for her invaluable help in locating material, and to this journal's anonymous readers for their comments. I remain responsible for all errors. Parts of this article also appear in Ian Brown, 'South East Asia: reform and the colonial prison', in Cultures of confinement: The history of the prison in Africa, Asia, and Latin America, ed. Frank Dikötter and Ian Brown (London: Hurst, 2007).

1 Alexander Paterson, Report on the prevention of crime and the treatment of the criminal in the Province of Burma (Rangoon: Government Printing and Stationery, 1926), Resolution, p. 1. 
on graduating in 1906, with a Third in literae humaniores, the honours course in classics, philosophy, and ancient history at Oxford, Paterson settled in Bermondsey, in one of the worst tenements on the riverside, where he was to live, except for the years of war service, for the following two decades. In 1908 Paterson became a director of the newly formed Borstal Association, responsible for the supervision of youths released on licence from Borstal institutions, and in 1911 he was appointed Assistant Director of the Central Association for the Aid of Discharged Prisoners, in which capacity he made monthly visits to every convict prison in the country to assess the needs of inmates due for release. On the outbreak of war in 1914, he enlisted in the Bermondsey battalion, serving in France, first as a private and later as captain. During the war, he was badly wounded, mentioned in dispatches, twice recommended for the Victoria Cross, and decorated with the Military Cross. Afterwards, he held a senior post in the Ministry of Labour, until, in 1922, aged just 38, he was appointed a Commissioner for Prisons, a position he would hold until he retired in 1947.

Paterson was a progressive, in the words of his Times obituary, 'one of the greatest of prison reformers'. His central principle was that prison almost invariably induced a mental and moral deterioration in its inmates, while its first purpose should be to reform and rehabilitate. Two of his best-known aphorisms were 'It is impossible to train men for freedom in a condition of captivity' and 'Men come to prison as a punishment not for punishment.' Although Paterson never became chairman of the Prison Commission, all accounts agree that it was his 'imagination and inventive force' that drove the work of the commission between the mid-1920s and the mid-1940s. These were the 'Paterson years'. In other words, the figure who arrived in Rangoon in late 1925 was no grey bureaucrat but, even at that early stage of his career, a powerful voice in the world of prison administration. ${ }^{2}$

\section{Questioning colonial Burma's prisons}

The prison system that Alexander Paterson had come to advise was certainly heavily used. In the mid-1910s the average daily inmate population as a proportion of Burma's total population was just under 140 per $100,000 .^{3}$ The corresponding figures for the United Provinces and Bengal were, respectively, a little over 50 and just under 30. In other words, an inhabitant of Burma was almost three times more likely to be sent to prison than an inhabitant of the United Provinces, and almost five times more likely than an individual in Bengal. Yet despite this heavy use, in the early 1920s Burma's senior prison administration was openly questioning the effectiveness of the prison as a modern institution for the treatment of the criminal, and, specifically, the capacity of Burma's gaols to reform and rehabilitate.

2 Basic accounts of Alexander Paterson's career and achievements can be found in The dictionary of national biography. Supplement 1941-1950 (Oxford: Oxford University Press, 1959), pp. 658-61; The Times, 10 Nov. 1947 (obituary); and Rupert Cross, Punishment, prison and the public: An assessment of penal reform in twentieth century England by an armchair penologist (London: Stevens, 1971), pp. 29-37. For a detailed, scholarly assessment, see W. J. Forsythe, Penal discipline, reformatory projects and the English Prison Commission 1895-1939 (Exeter: University of Exeter Press, 1991). And for the voice of the man himself, see Paterson on prisons: Being the collected papers of Sir Alexander Paterson M. C., M. A., ed. S. K. Ruck (London: Frederick Muller, 1951).

3 Calculated from Report on the Prison Administration of Burma (henceforth RPAB), 1915, Statement A. 
This questioning ignited - though the issue had arisen a few years earlier - in the aftermath of the publication of the report of the Indian Jails Committee of 1919-20. The resolution on the 1921 report on the prison administration of Burma noted the committee's view that 'efforts should be made to concentrate upon reformative treatment' in the gaols of British India. ${ }^{4}$ As if in direct response, in the 1921 report itself, the Inspector General of Prisons, Burma, Major H. H. G. Knapp, declared that while there was nothing in the 'physical or mental make-up' of the Burmese criminal that would prevent him from being 'reformed' and made 'fit for freedom', he, the Inspector General, remained sceptical 'as to the possibility of reforming him within the walls of a jail'. ${ }^{5}$ The following year, 1922, Major Knapp posed the fundamental question. 'With what object do we put men into prison? [After all the] prison system [is] a comparatively modern method of dealing with delinquents, and so may be said to be still on trial. ${ }^{36}$ Responding to his own question, he outlined the standard points. But his position was that, with respect to a number of them, the prison was failing. It did not deter crime. Neither did it reform the criminal: 'We must, I fear, admit that our jails are not, and probably cannot be made, reformatories." They were failing to reform in part because, in Burma's prisons, hardened criminals were freely associating with the casuals, and thus contaminating them. But more fundamentally, Major Knapp continued, a man sent to prison - by implication, any prison, anywhere in the world rapidly learnt to adapt to the gaol routine, learnt to survive and perhaps prosper. But that process of adapting was the worst possible training for life back in society: 'Many of our "good" prisoners [that is, those who adjusted well to the prison regime] leave jail thoroughly bad citizens.'

Some men do make themselves fit for freedom while in jail, but they are few, and they do it in spite of, and not because of, the jail system. I do not believe it is possible to fit a man for freedom so long as he is kept in unnatural surroundings... [we should] explore fully every alternative to jail ... The direction of prison reform should have as its aim the closing of jails rather than the building of more of these costly institutions. ${ }^{9}$

Presumably few heads of a prison administration, anywhere, can have called for the closing of gaols, at least publicly, as here.

Major Knapp retired in 1924. His successor, Major P. K. Tarapore, was of a similar mind, aware that, as he put it in one of his first annual reports, 'prison methods are fast changing. ${ }^{10}$ In an early initiative, he proposed the introduction of Borstal institutions and a probation service, both alternatives to prison - and both clearly Paterson territory. ${ }^{11}$ Major Tarapore was also eager to learn from the experience of prison administrations elsewhere, and to engage with the most recent penological thinking and practice. In 1924 he visited gaols in Madras, Bengal, Bombay, United Provinces,

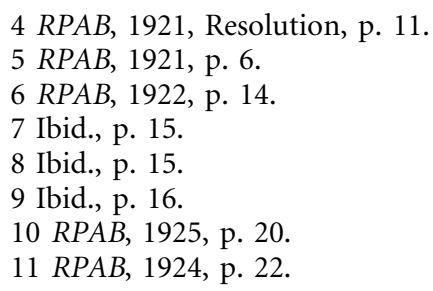


and Central Provinces. ${ }^{12}$ And while on leave in Europe in the same year, he took the opportunity to examine closely prison administration in England. Here, surely, the Inspector General met the recently appointed Prison Commissioner, their like-minded approach to the treatment of the criminal was discovered, and the plan for Paterson to visit Burma was hatched.

Paterson spent four months in the province, and was characteristically energetic. In addition to gathering and working his way through a substantial body of data and opinion, he inspected most of the important gaols, visited the penal settlement in the Andaman Islands, examined possible sites for a training school for young offenders, and delivered public lectures in Rangoon on crime and the treatment of the criminal. ${ }^{13}$ He also led a jungle camp for young offenders, 16 inmates of the juvenile gaol at Meiktila - murderers, dacoits, rapists, and thieves. In this he was assisted by a Burmese, Pe Maung Tin, Professor of Oriental Languages at Rangoon University, and three other Europeans, an official from the Borstal Association in England, the government's advisor on physical training, and a captain in the Burma police. For a week, with no guards, the community built a road, worked through tough physical exercises, played team games and swam in the lake, sang songs, studied Burmese history, and were instructed in Buddhism by a local monk. ${ }^{14}$ As the group had set off for the camp, '[t]he betting in the clubs of Rangoon was 10-1 against [Paterson] returning alive'. ${ }^{15}$ But at the end of the week, Paterson and his colleagues emerged unscathed, while the 16 convicts - 'smiling lads' - returned to the Meiktila gaol to complete their sentences.

\section{Paterson's report}

Alexander Paterson's Report on the prevention of crime and the treatment of the criminal in the Province of Burma was published by the Burma government in 1926. It is divided into three parts. The first considers the causes of crime in Burma and its prevention, the second, the treatment of young offenders. But the focus here is on the final part of the report, which focuses on Burma's gaols and the punishment of the province's convicts.

Paterson opened with some big numbers. Burma, with a population of roughly 13 million, was sending about 20,000 men to prison each year. Two-thirds were being sent for the first time; and five out of six inmates had been convicted of some crime against property, such as theft, housebreaking, or fraud. On any one day, Burma's gaol population numbered some 16,000 :

No one visiting the great jails of Burma, studying first the 2,600 first offenders at Rangoon, and then the 2,500 habitual prisoners at Insein, can forbear from asking the simple question - what is the good of it all? What purpose has been served by dragging all these men from earning a livelihood with their wives and families (as the majority of

12 Ibid., pp. 20-1.

13 Paterson, Report on the prevention of crime, Resolution, p. 1. This would appear to have been Paterson's first visit to Asia - he also visited Ceylon to offer advice on the prison administration - and his last.

14 Paterson published a brief account of the week, 'A Borstal camp in Burma', in the Rangoon Gazette Weekly Budget, 8 Mar. 1926, p. 22. The account was republished in Paterson on prisons, pp. 179-82. 15 Paterson on prisons, p. 13, footnote 1. 
them were doing) and enforcing upon them this highly artificial life within walls, where they do very little work and cost the Province over 20 lakhs every year? What effect has it on them or the world outside? Can no more effective and less expensive way be found to meet the end for which prisons were designed ${ }^{16}$

And later:

The main criticism of the jails of Burma ... is that there are too many people in them... There has been little clear thinking on the subject of prisons, their purpose, their method and their effect, among the general community. They are accepted as necessary and convenient evils, with a hope that they are not too expensive ... Committal to prison is the refuge for a community that will not take the trouble to think of any other way of dealing with a troublesome person. ${ }^{17}$

Paterson proposed three measures that would, he suggested, roughly halve Burma's prison population. The first two were modest in both nature and potential impact - the introduction of a probation scheme, open principally to first offenders, young and old, and the creation of residential schools for young offenders, aged 14-18. His third was more radical. Paterson proposed that normally no convict should be held in prison for more than two years:

It is very doubtful whether after two years any good is done to a man by further detention in the circumstances of jail-life. He will get used to it, relapse into the halflight of a monotonous regime, lose count of time and space, and become daily more fitted to be a prisoner than a free man. ${ }^{18}$

It followed that the prison should focus on the initial reform of the convicted criminal, instilling in him discipline and the habit of hard work. ${ }^{19}$ At the end of two years, which should see the completion of that initial reform of character, convicts - of course only those sentenced to more than two years - would be 'at the disposition of the state'. First offenders, except those convicted of murder or dacoity, would be organised into labour gangs and, under the direction of the Public Works Department, be put to work on road construction or the clearing of forest for cultivation. They would be joined by wives and families, live in temporary structures close to the work site, and be paid the wages of a free labourer. There would be no guards. Idle workers would be returned to the prison. In contrast, habitual offenders, again except those convicted of murder or dacoity, would be sent to an island settlement - Paterson identified Cocos Island and the island of Pyinzalu, on the southern edge of the delta, as possible sites. There they would be free within the limits of the settlement, would again be joined by wives and families, and would be expected to be self-supporting, perhaps from the processing of the coconuts that grew locally in abundance. Finally, Paterson proposed that murderers and dacoits would not be subject to the initial two years of imprisonment but rather, on conviction, would be sent immediately to the penal

16 Paterson, Report on the prevention of crime, p. 46.

17 Ibid., pp. 61-2.

18 Ibid., pp. 62-3.

19 Ibid., pp. 63-7. 
colony in the Andaman Islands. These convicts too would be joined by wives and families.

Paterson's first concern in this final part of his report was, therefore, a sharp reduction in Burma's prison population - since long-term imprisonment left men even less fitted to live an honest life outside. His second was an improvement in the gaol staff, to ensure that short terms in prison, in contrast, would indeed reform and rehabilitate Burma's criminals. Starting at the most senior level, Paterson noted that in 27 of the 31 gaols in the province, the post of prison superintendent was being held on a part-time basis - 'a few spare hours' - by the local civil surgeon:

They sign their names upon a hurried series of forms, they hear applications from, and administer justice among, prisoners whose language is usually a closed book to them. They are compelled to accept from the Chief Jailor and his subordinate jailors, not only their interpretation of all that a prisoner says, but also their account of all that happens in the jail itself. Their conception of a jail rarely goes further than supposing all is well if the prison is clean, and the prisoners quiet, the accounts correct, and there are no escapes. They have neither the time nor the experience to face such a pungent question as to whether a man is worse or better for spending five years in their jail. ${ }^{20}$

Paterson proposed that a full-time superintendent be appointed for each gaol in the province and, moreover, that each prison superintendent be required to speak to 'his' prisoners in Burmese.

Immediately below the superintendent were the gaolers of various rank - chief gaoler, deputy gaoler, and gaoler - some 150 in all across Burma's prison system. According to Paterson, within the prison staff, only the gaolers (together with the convict officers, to be considered below) spoke Burmese, and understood, in its broader sense, the inmates. Partly for this reason, and partly because the superintendent was usually absent, the gaolers ran the administration of their prison: 'very little ... can be done without them'. ${ }^{21}$ Paterson proposed that the number of gaolers be increased, their working hours reduced and promotion from chief gaoler to superintendent be opened up.

Below the gaolers were the prison warders, roughly 1,000 across all Burma's prisons. The warders were Indians, recruited mainly from the United Provinces. ${ }^{22}$ Several attempts were made around this time to appoint locals - in 1926 Burman warders were employed at the Tharrawaddy and Mandalay gaols 'as an experimental measure' - but with little success. ${ }^{23}$ The absence of Burmans might be explained in part by their reluctance to seek work in a sector where Indian domination was now complete, not least because the entrenched Indians would not have welcomed Burman

20 Ibid., pp. 53-4. Not only the 27 part-time superintendents but also, Paterson noted, three of the four full-time prison superintendents were medical men - members of the Indian Medical Service. This point is taken up later.

21 Paterson, Report on the prevention of crime, p. 54. Many, if not most, of the gaolers were European, some serving in Burma for decades and thus, presumably, fluent in Burmese. In 1900, first grade gaoler Lecun retired after 33 years service. He was presented with a gold watch by the Lieutenant-Governor; $R P A B, 1900$, p. 11.

22 RPAB, 1923, p. 18.

23 RPAB, 1926, p. 10. 
interlopers. But also important was the low pay, a mere 20 rupees a month, clearly insufficient to attract Burmans. However, as Paterson pointed out, the low wages being offered to warders not only excluded the local population but also attracted merely the least able Indians, who, moreover, inevitably supplemented their meagre wages by all manner of illicit dealings - for example, smuggling tobacco and opium into the gaol. ${ }^{24}$ But the failing of the Indian warders in Burma's prisons went far further than this: 'the Burman instinctively regards [the Indian] as inferior, and real discipline can never exist where those in authority are openly despised. The youngest prisoners may be seen openly flouting the control of their Indian warders. ${ }^{25}$ Paterson proposed the gradual abolition of the Indian warder in Burma and the recruitment of Burmans in his place. The latter would require a substantial increase in warder wages, a reduction in working hours and an increase in numbers, and the opening up of promotion from warder to gaoler.

Below the warders, on the lowest level, were the convict staff, which had been selected from among the more trustworthy and less criminal inmates for positions as overseers, watchmen, and guards. According to Paterson, convicts were used in these positions in Burma's prisons not with the aim of reforming their character, which might be achieved by instilling in them a sense of responsibility and self-esteem, but simply in order to save money. ${ }^{26}$ The convict staff received no pay but certain privileges - for example, noted in the annual report for 1905, special articles of bedding, an issue of meat or fish once a week, a twice daily smoke, and a piece of soap instead of sooji muttee. ${ }^{27}$ Paterson's view on the use of convict staff was sharply divided. On the one hand, they were an absolutely vital element in the running of the province's gaols - in large part because the Indian warders immediately above them, unable to speak Burmese and despised by the Burmese prisoners, were so ineffective: 'Without the jailors and the convict warders, the whole system would collapse like a pack of cards. ${ }^{28}$ On the other hand, it was clear that, all too often, convict staff used their position to exploit and abuse the ordinary inmates. The annual reports on Burma's prison administration in this period often included accounts of convict staff stealing from prisoners, and assaulting and terrorising those in their charge. ${ }^{29}$ 'The system of convict officers, overseers and night watchmen', Paterson concluded, 'is cheap and nasty', and he proposed that the powers of the convict staff be reduced until they had no authority over other inmates. ${ }^{30}$ The strengthening of the authority of the warders that would come with the replacement of the Indians by Burmans, would in itself 'put the convict officer in his proper place'.

Paterson made a number of further recommendations, some minor, others more substantial. He proposed the appointment of a 'controller of jail industries', who would

24 Paterson, Report on the prevention of crime, p. 55.

25 Ibid.

26 Ibid., p. 56.

$27 R P A B, 1905$, p. 6. The literal meaning of sooji muttee is 'semolina mud' but by extension perhaps a form of coarse soil - the sense of sooji lies in its granular quality - used in washing the body. I am grateful to my colleagues. Dr Daud Ali and Dr Jeevan Deol, for these tentative insights.

28 Paterson, Report on the prevention of crime, p. 55.

29 The rape of prisoners by convict officers was not uncommon; see, for example, a reference to the rape of a newly admitted prisoner by three convict staff in the Mandalay Gaol in 1915, in RPAB, 1915, p. 6 . 30 Paterson, Report on the prevention of crime, p. 56. 
more effectively organise the prison labour regime in the province, to ensure that each inmate was worked hard each day. ${ }^{31} \mathrm{He}$ also proposed the establishment of special gaols for men aged between 19 and 25, with a more demanding labour regime, more education classes, and ' $\mathrm{t}$ ] wice a week route marches for ten miles in the surrounding country'. ${ }^{32}$ It is interesting to note, however, that, although invited to Burma 'to advise generally on Jail conditions' in the province, Paterson felt no need to offer recommendations with respect to such basic conditions as the prison diet, medical provision, the inmates' sleeping, eating or working environment, educational and training provision, or the punishment regime - except that he recommended that the rattan cane be replaced by the cat-o'-nine-tails. No huge failures in the prison administration were identified, no horrors exposed, beyond the fact that such large numbers of Burmese found themselves in prison. This might suggest that Paterson found conditions and practices in Burma's prisons that were not vastly dissimilar from those in English gaols.

The Burma government's response was established in the Resolution published as the preface to Paterson's report. Some recommendations were accepted, others were already being implemented, and others still would be carefully considered. Thus the administration was already considering a scheme that would remove a number of inmates from Burma's overcrowded prisons to serve out their sentences in labour gangs, making roads, or working government-owned quarries. Indeed, in the late 1920s, two camp gaols, each located at a government stone quarry, were established, the first at Alon in the Lower Chindwin district (northwest of Mandalay) and the second at Mokpalin in Thaton district (east of Rangoon). In the mid-1930s, the two camp gaols, which were temporary structures, held one-eighth of Burma's convict population. At the time it received Paterson's report, the administration was also already in the process of appointing, as the Commissioner would propose, a Supervisor of Jail Industries. In mid1931 a combined Borstal and Senior Training School, under a superintendent brought out from England, was opened at Thayetmyo in central Burma. ${ }^{33}$

Elsewhere, the Burma administration saw practical difficulties, even when it favoured Paterson's proposal. Thus although the administration had long been considering the establishment of a probation system - indeed this had been a recommendation of the Indian Jails Committee, 1919-20 - the initiative had floundered mainly over the problem of finding sufficient suitable probation officers in the province. ${ }^{34}$ The administration had long wished to replace the Indian prison staff with Burmans; but Burmans had shown no inclination to apply for prison work. It had often considered reducing the use of convict staff - but to increase the number of paid prison staff was felt to be prohibitively expensive.

Finally, certain Paterson proposals were rejected outright by the Burma administration. Murderers and dacoits would not be sent to the Andaman Islands, since the government of India, whose territory this was, had recently abolished convict transportation. ${ }^{35}$ The provincial administration would not be establishing its own

31 Ibid., pp. 57-60.

32 Ibid., pp. 51-2.

33 Paterson, Report on the prevention of crime, Resolution, pp. 4-5; RPAB, 1927, pp. 10, 14; RPAB, 1928, p. 6; RPAB, 1931, p. 1; RPAB, 1935, p. 2.

34 Paterson, Report on the prevention of crime, Resolution, pp. 3-4. 
island settlements for habitual offenders, although it had given the issue careful consideration, since suitable sites - extensive cultivable land, ease of access by ship throughout the year - could not be found. There remained Paterson's pivotal recommendation that 'no man should stay for more than two years in a walled jail', a proposition that invited the Burma government to rethink the very purpose of the prison, and to create a new structure that would more effectively reform and rehabilitate the criminal. The government dismissed it without comment. But then perhaps few administrations, at the time or since, would have embraced that radical position. ${ }^{36}$

\section{Colonial Burma and penal thinking}

The main importance of Alexander Paterson's visit to Burma lies not in the poor response of the colonial government to his report. In practical terms, he did indeed achieve relatively little. ${ }^{37}$ Rather, the importance lies in the insight it provides into the thinking within the Burma prison administration at that time and, in particular, into the Burma administration's relationships with the international community of prison administrators and thinkers, relationships that stood outside the formal structures of colonial government and imperial authority.

From the account above, it is clear that Paterson was not imposed on Burma by London. It was not the case that the India Office, faced with a crisis in Burma's gaols, was forced to dispatch a senior prison official to Rangoon to sort things out. Indeed the India Office was not involved in any way with the invitation to Paterson; there was no communication with either the local government in Rangoon or the Prison Commission in London. ${ }^{38}$ Neither, it would appear, was it a case of the Burma government being forced to call in help from London to sort out a breakdown in the

\section{Ibid., p. 4.}

36 Ibid. That Paterson combined hard practicality with near-utopian vision was caught in the oneparagraph review of his report that appeared in the Rangoon Gazette Weekly Budget (13 Dec. 1926, p. 21). He was 'a man with his head among the stars and his feet on solid ground.' The reviewer was probably J. S. Furnivall. I am grateful to Bill Elkins for this last point.

37 One significant impact, outside government, must be noted. During his time in Rangoon, Paterson came to know Professor G. H. Luce and his Burmese wife, Daw Tee Tee, and undoubtedly talked with the couple about his earlier work among the young in south London. When Daw Tee Tee went to England later in 1926 to settle her two children in school, Paterson arranged for her to visit juvenile courts, Borstals, prisons, and correction homes. On returning to Burma, she began working with the street children of Rangoon, and in September 1928 established the Home for Waifs and Strays. Supported in large part by private contributions - the Rangoon Corporation and the Chinese Central Club also made substantial donations - by 1941 the home consisted of 12 buildings. In January 1942, with the Japanese advancing on Rangoon, the Luces were forced to leave Burma, and the home was closed. But they returned after the war, and re-established the home. In the late 1950s, the Luces, together with John Furnivall, occupied rooms on the second floor. In 1959, Daw Tee Tee received the Ramon Magsaysay Award for Public Service. This account draws on a posting on the Ramon Magsaysay Award website: http://www.rmaf.org.ph/Awardees/Citation/CitationLuceTee.htm (accessed 1 Dec. 2006).

38 The first reference to Paterson in the India Office files came in late November 1926 - following the publication of his report - in the preparation of an answer to a parliamentary question (22 Nov. 1926). There was a further reference a few months later (Minute, 7 Mar. 1927), when the India Office was being asked for copies of the report. On both occasions it was simply noted that Paterson had been invited to Burma 'without the intervention of the India Office'. Oriental and India Office Collections, L/PJ/6/1929: Files 2940, 3298. 
local prison administration: not least, there was no such failure, demanding such an intervention. ${ }^{39}$ Rather the idea to invite Paterson to Burma to offer advice on gaol conditions in the province almost certainly came from the Burma prison administration itself. And indeed it is possible to identify the point at which the idea may have arisen, the occasion on which the initial contacts between the prison commissioner and Burma's senior prison officials were made. As noted earlier, in 1924, the Inspector General of Prisons, Burma, Major P. K. Tarapore, took the opportunity of leave in Europe to examine prison administration in England. $\mathrm{He}$ surely met Paterson. Then in August 1925, the International Penitentiary Congress, a gathering of prison administrators and penologists from across the world, which took place once every five years, was held in London. Alexander Paterson was, of course, a prominent presence in the proceedings. The Burma delegate, part of the British India delegation, was not Major Tarapore, but his immediate predecessor as Inspector General, Lt.-Col. H. H. G. Knapp, now retired. ${ }^{40} \mathrm{He}$ too surely met Paterson. Just three months later, Paterson arrived in Rangoon.

On prison matters, Paterson and Knapp - and almost certainly Tarapore as well were of similar minds. As noted earlier, as Inspector General of Prisons, Knapp had stated in public that he was sceptical 'as to the possibility of reforming [the Burmese criminal] within the walls of a jail', and that the 'direction of prison reform should have as its aim the closing of jails rather than the building of more of these costly institutions'. Such beliefs were parallel to Paterson's. In inviting the Commissioner to Burma, therefore, Knapp and Tarapore were seeking to strengthen their position in some way. There were two possible circumstances. Perhaps Knapp and Tarapore were in conflict with the local government or with their subordinates in the Burma prison administration over some major aspect of prison policy or practice in the province, and were bringing in Paterson to make sure their views would prevail. But this is unlikely. There is no evidence of such a rift, and to judge by the local government's response to the Paterson report, this was a strategy that was unlikely to succeed. The more probable circumstance was that, having advanced their radical views - and it was undeniably radical for the Inspector General of Prisons to argue, in effect, that the prison was a failing institution - Knapp and Tarapore were now seeking to explore these views further, guided by a major authority in prison thinking. Paterson was to be a mentor, who would strengthen their understanding.

If this was indeed the sequence of events, then from where did the radical impulse that took hold of Knapp, in particular, arise? Part of the answer undoubtedly lies in the

39 I have been unable to find a file in the National Archives Department in Yangon, concerned with the Paterson visit, to substantiate this point. With regard to the London materials, Sir Alexander Paterson's personnel files at the Prison Commission (now held at The National Archives, Kew, HO 45/21687) contained one file, 'Mr. Paterson's visit to Burma'. Sadly, that file was destroyed when the records were moved from the Home Office to Kew. No sinister motive is imputed; it is far more likely that the Home Office weeder simply saw the file as having no historical value. But the silence of the archives in Rangoon and London means that the account to be given above as to who first thought of inviting Paterson and who made the first contacts with him - and these are not narrow details but important elements in the main argument - remains conjecture.

40 Actes du Congrès Pénitentiaire International de Londres, Août 1925 (Berne: Bureau de la Commission Pénitentiaire Internationale, 1927), vol. 1b, p. 27. 
character of the Inspector General. But I wish to focus here on a crucial structural factor. The Inspector General of Prisons in colonial Burma was invariably a member of the Indian Medical Service (IMS), holding a military commission. In other words, he was an army surgeon. Almost all prison superintendents, from whose ranks the Inspector General was usually appointed, were also army surgeons. The purpose of this structure, which was applied across British India, was to provide a major part of the medical reserve for the army. An army naturally requires a far larger medical establishment when fighting than during peacetime; yet during periods of peace, it must maintain the full complement in reserve, ready to be mobilised at short notice. In British India, this had long been secured by reallocating army surgeons to civilian positions during peacetime. They supervised dispensaries, staffed medical schools and research institutes, took charge of the sanitary administration, and ran civil hospitals, mental asylums, and prisons. In 1910, roughly three-fifths of the IMS establishment was allocated to civilian positions. ${ }^{41}$

To entrust the running of the prisons, and indeed the most senior position in the prison administration, to army surgeons on reserve, was controversial. Paterson was certainly critical, arguing that the 'superintendence of a jail is a highly technical piece of work, a skilled profession in itself, and cannot be performed ... by men wholly untrained for it'. ${ }^{42}$ He called for the connection with the Indian Medical Service to be severed, and the creation of a fully separate, properly trained and experienced, prison administration. Evidence taken by the Indian Jails Committee of 1919-20 had also been critical. ${ }^{43}$ It was reported that many IMS officers, for whom being superintendent of the local gaol was just one of many responsibilities, carried out their prison work in a perfunctory manner. They merely signed a few documents without thought or question, made an occasional tour of their gaol, and carried out a hurried examination of the more serious cases in the prison hospital. Most of their prison work required the presence of an interpreter, which isolated the superintendents still further from the day-to-day running of their gaols. Some IMS officers positively disliked their prison work because it brought them more responsibility for only a small lift in salary, while preventing them from working in potentially lucrative private practice, or because they felt in some way tainted by the association with prisons and convicts. Finally, one witness to the Indian Jails Committee reported that an IMS officer seen to be ineffective in his medical work was likely to be shipped out to run a gaol. The prison administration in British India was a dumping ground.

41 It followed that when the medical reserve was mobilised on the outbreak of hostilities, the civilian institutions in which the army surgeons had been deployed found themselves stripped of their senior staff. During World War I, a number of Burma prison superintendents were recalled to military duty; see, for example, $R P A B, 1917$, p. 17. Major Tarapore, IMS, who had become superintendent of the central gaol in Mandalay in July 1914, was returned to military service the following October, and he remained with the army until March 1920; India Office List, 1928; David Arnold, Colonizing the body: State medicine and epidemic disease in nineteenth-century India (Berkeley: University of California Press, 1993), p. 62.

42 Paterson, Report on the prevention of crime, pp. 53-4. As noted above, Paterson's further concerns here were that these medical men were, in most cases, running a prison on a part-time basis, 'a few spare hours', and that they were being appointed to the position of prison superintendent, part-time, 'by the mere accident of their being Civil Surgeon in the area'.

43 Arnold, Colonizing the body, pp. 101-2. 
But there were also IMS officers who were undoubtedly attracted to prison administration. The Indian Jails Committee heard that prison provided considerable, interesting, clinical work and, perhaps more importantly, excellent opportunities for carrying out research, notably in the field of preventive medicine. The committee also heard - in evidence from the Madras Inspector General of Prisons - that the IMS officer was 'peculiarly suited' to running a gaol. 'He is a trained scientist with expert knowledge in military law, organization, administration, sanitation, psychiatry and tropical medicine. ${ }^{44}$

Perhaps there was a further, broader, consideration. Trained and experienced in one field, in moving into prison administration, the army surgeons - at least those who took their new responsibilities seriously, took charge of a major gaol such as Rangoon or Insein, or rose to the position of inspector general of prisons - had to develop a new expertise and to learn a quite different discipline. That circumstance shaped their administration of Burma's prisons in three ways. The prison authorities in Burma, reflecting their medical background, paid considerable attention to the physical health of inmates, and indeed achieved a marked reduction in prison mortality by the final decades of colonial rule. ${ }^{45}$ Second, and of greater importance here, coming into prison administration, the army surgeon-prison superintendent was perhaps more likely to ask basic questions when exercising his new expertise. 'With what object do we put men into prison?', asked Major Knapp, MA, MD, IMS, in the annual report of the Burma prison administration for $1922 .{ }^{46}$ That was a question far less likely to be raised by a senior prison official whose entire career had been built in a prison administration, at least not in public and so directly. Nor was the latter likely to provide Knapp's response that prison reform should seek the closing of prisons. Third, IMS officers sent to run Burma's prisons honed their new expertise - in much the way as medical men - by reading the specialist literature, attending conferences and congresses, and by calling in 'consultants'. ${ }^{4}$ Burma's prison administration was tied into international networks of prison practice and thinking.

In colonial Southeast Asia, such integration was common. It is interesting to note, for example, that the 1925 International Penitentiary Congress - when Knapp met Paterson - was also attended by the Assistant Director of the Philippine prison administration, the Attorney-General of the Straits Settlements, a first secretary from the Siamese Legation in London, and a former Director General of prisons in the

44 Quoted in Arnold, Colonizing the body, pp. 101-02.

45 I have considered this point at length in Ian Brown, 'Death and disease in the prisons of colonial Burma', in Medicine in Myanmar: The colonial era, ed. Monique Skidmore, forthcoming.

46 RPAB, 1922, p. 14.

47 On occasion, the inspector general's professional reading surfaced in the annual reports. That for 1885 included references to an article by the Honourable Mr Justice Stephen, 'Variations in the punishment of crime', that had appeared in a recent issue of the Nineteenth Century, and to The punishment and prevention of crime by Sir Edmund Du Cane, the first chairman of the Prison Commission, that had been published that same year: $R P A B, 1885$, pp. 6-7. Senior Burma officials were sent to India-wide gatherings - Major Tarapore attended the second Conference of Inspector-Generals of Prisons, held at Oolacamund, Madras, in Oct.-Nov. 1925; RPAB, 1925, p. 28 and, of course, there was a Burma representative at the International Penitentiary Congress in London in August 1925. 
Netherlands East Indies. ${ }^{48}$ In her study of the prison system of the Netherlands East Indies in the final decades of colonial rule, Anne Marie Christien Bruinink-Darlang refers to the 'cosmopolitan mentality' of many of the Dutch prison officials of that time, their interest in new ideas. ${ }^{49}$ These were often stimulated, she argues, by visits to prison administrations in the United States, China, and Japan as they made their way to the Netherlands on leave. Interestingly, she also argues that in the reform of its prison administration in this period, the Netherlands East Indies was often two decades or more ahead of the Netherlands itself, for example, in the classification of inmates, in the establishment of a separate institution for young offenders, and in the provision of training courses for prison officials. The colonial prison administration, she suggests, had more freedom to experiment than its metropolitan counterpart.

The prison administration in the American Philippines - largely Filipinised by the 1920 s - kept closely in touch with prison practice and thinking in the United States. Its directors and assistant directors frequently crossed the Pacific to inspect American gaols, and to attend and address annual meetings of the American Prison Association. ${ }^{50}$ Some progressive American thinking came back across the Pacific, perhaps most clearly seen in the establishment of the Iwahig Penal Colony, on the island of Palawan, in 1904. Iwahig was run principally by the convicts themselves - there were astonishingly few non-convict officials and no guards - taking as its model the George Junior Republic, 'a reformatory school for delinquent and wayward children' in upstate New York. ${ }^{51}$ The Philippine prison administration was tied into international networks of prison practice and thinking in a further, distinctly unusual, manner. For the marked number of overseas visitors who came to Manila in the 1920s, arriving on the tourist liners that now called regularly at the port, Manila's prison, Bilibid, was a major attraction on the city tour. ${ }^{52}$ Stationed on a gallery built on the roof of the prison's central tower, the visitors came to watch the retreat at the end of the inmates' working day, a routine that included an impressive display of mass gymnastics and a performance by the Bilibid band. That exposure, although clearly superficial, projected Bilibid as a progressive institution, and thus it became an element in the Philippine administration's alignment with modern prison thinking. ${ }^{53}$

48 Actes du Congrès Pénitentiaire International de Londres, vol. 1b, pp. 30, 31, 32. There was no representative of the French Indo-China prison administration at the London congress.

49 Anne Marie Christien Bruinink-Darlang, Het penitentiair stelsel in Nederlands-Indie van 1905 tot 1940 [The penal system of the Netherlands East Indies from 1905 till 1940] (Alblasserdam: Kanters, 1986), p. 417.

50 For example, the then Director of Prisons, Manila, Waller H. Dade, MD, addressed the 1916 Congress of the American Prison Association, held in Buffalo, on the 'Prison system of the Philippines': text in the National Archives of the United States at College Park, RG 350, 6281-16. As noted above, the then Assistant Director, Manuel Alzate, attended the international congress in London in 1925.

51 Michael Salman, "Nothing without labor": Penology, discipline, and independence in the Philippines under United States colonial rule, 1898-1914', in Discrepant histories: Translocal essays on Filipino cultures, ed. Vicente L. Rafael (Philadelphia: Temple University Press, 1995), pp. 119-20; and, John Lewis Gillin, Taming the criminal: Adventures in penology (New York: Macmillan, 1931), pp. 54-61. 52 Annual report of the Governor General Philippine Islands, 1924 (Washington, DC: Government Printing Office, 1926), p. 165; Gillin, Taming the criminal, pp. 45-6.

53 The complimentary comments of Bilibid's visitors were proudly reported. 'Best discipline and spirit have yet seen in a prison' (Congressman M. G. Maas); 'Wonderful discipline and a credit to the country' (Louis G. Clook); 'I came from a prison city but your prison is far superior to ours' (Paul R. Clark): 


\section{The prison and colonial rule}

A prison regime reflects the society in which it is embedded - or perhaps more accurately it reflects the political imperatives and societal perceptions, even on occasion the economic requisites, of those who rule. It is for this reason that the prison is so revealing of broader social and political structures, and that the distinguishing detail and direction of a prison regime can capture so effectively the ambitions, interests, and understandings of the ruling elite. The penal regime in French-ruled Vietnam, taking an example from colonial Southeast Asia, was defined in large part by the fact that the prison there became a major battleground in the struggle between French repression and Vietnamese anti-colonialism. ${ }^{54}$ For the Indo-Chinese Communist Party, the prison provided opportunities for political education and for constructing a revolutionary organisation, while a term of imprisonment for some revolutionary act, and the status of 'political prisoner', could confer on an individual great prestige within the movement and among the broader population. The prison thus had a central role in fostering Vietnamese political consciousness and organisation under French rule. For the French administration, seeing the prison as a battleground, as an instrument to break its nationalist opponents, closed off any thought of using the prison regime to reform and rehabilitate the criminal. In his fine study of imprisonment in colonial Vietnam, Peter Zinoman has argued that 'one of the most remarkable aspects of the prison system in French Indochina was its utter failure to deploy disciplinary practices' - the concept of recasting the character of the criminal by means of discipline. ${ }^{55} \mathrm{He}$ explains this failure in terms of:

[the persisting influence of] preexisting Sino-Vietnamese carceral traditions in which discipline [to reform the criminal character] played only a minor role ... [the fact that the prison in colonial Vietnam] evolved directly out of the prisoner-of-war camp, an institution that was repressive, not corrective ... [an assertion that] the essentially racist orientation of the colonial state [and] the growth of a conviction in nineteenth-century French criminology that some lawbreakers were innately incorrigible, discouraged belief in the value or indeed the feasibility of employing discipline to modify the behavior of non-European lawbreakers [and finally] the extremely tightfisted character of the colonial state and its stubborn refusal to provide the resources necessary for the creation of a truly disciplinary penal system. ${ }^{56}$

Annual report of the Governor General of the Philippine Islands, 1927 (Washington, DC: United States Government Printing Office, 1928), p. 232.

54 Dramatically so in the early 1930s, which saw a huge wave of arrests and imprisonment in the wake of the depression-era rebellions. Between 1929 and 1932, the prison population in Vietnam increased by 75\%. In 1933, the French League for the Rights of Man put the number of political prisoners in IndoChina at about 10,000. Peter Zinoman, The colonial Bastille: A history of imprisonment in Vietnam, 18621940 (Berkeley: University of California Press, 2001), pp. 204-6.

55 Zinoman, The colonial Bastille, p. 16; but see also Peter Zinoman, 'The history of the modern prison and the case of Indochina', in Figures of criminality in Indonesia, the Philippines, and colonial Vietnam, ed. Vicente L. Rafael (Ithaca, NY: Cornell University, Southeast Asia Program, 1999), p. 161, for a more circumspect statement of this point. As noted earlier, there was no representative of French Indo-China at the International Penitentiary Congress, the principal international forum for the discussion of prison administration and practice, in London in 1925.

56 Zinoman, The colonial Bastille, pp. 16-17. 
But by the 1920s, and certainly the early 1930s, the context here was the fierce struggle between French rule and Vietnamese political consciousness, in which the prison was centre stage.

The prison in British Burma was not a political battleground. This surely reflected the fact that there was no sustained violent challenge to the colonial regime in Burma to compare with that in French-ruled Vietnam in the 1920s and 1930s. Burma's nationalist leadership was part of the colonial administration, not engaged in a violent conflict with it. There were relatively few political prisoners, and many of those were Indian nationalists serving their sentence in a Burma gaol. And although there was a wave of arrests in the wake of the Hsaya San rebellion at the beginning of the 1930s, there were few 'professional revolutionaries' among the hundreds sent to prison - in contrast to Vietnam - but overwhelmingly the rural dispossessed who had been caught up in the rising. No tight-knit revolutionary organisation was rebuilt in Burma's gaols in the 1930s, again in contrast to Vietnam.

The 'default' position in Burma's prison regime was still repressive. But it was a repression shaped principally by British perceptions, first, of Burmese 'criminality', and second, perhaps as important, of the 'criminal classes', a concept that clearly applied far beyond colonial Burma. A central British observation, frequently made, was that Burma was 'the most criminal province' in British India. ${ }^{57}$ At a simple level, this was no more than a statement of some basic statistical data, for, as noted earlier, colonial Burma was sending a much greater proportion of its population to prison than other Indian provinces. But the observation had a deeper resonance, as 'Burma is the most criminal province in British India' could easily become, by implication, 'the Burmese are the most criminal people in British India'. This need not be a racial argument, and in fact commonly was not. The Burmese were highly criminal, the argument ran, not by nature but because of the specific social and economic, perhaps administrative and political, circumstances in which they found themselves. Thus the report of a government committee appointed in 1923 to examine the causes of a recent increase in violent crime in rural Burma identified as an important long-term circumstance 'a loss of moral and religious instruction in the training of the young. ${ }^{58}$ This had arisen with the decline in the provision of traditional monastic education under British rule and the growing popularity of state-aided lay schools. The classic colonial study of the Burmese people by Fielding Hall explained soaring criminality explicitly in terms of circumstance:

Certain forms of crime are very rife in Burma. The villages are so scattered, the roads so lonely, the amount of money habitually carried about so large, the people so habitually careless, the difficulty of detection so great, that robbery and kindred crimes are very common ... Under like conditions the Burman is probably no more criminal and no less criminal than other people in the same state of civilization. Crime is a condition caused by opportunity, not by an inherent state of mind... ${ }^{59}$

57 See, for example, the Resolution on the prison administration report for 1915, p. 1.

58 Report of the Crime Enquiry Committee, 1923 (Maymyo: Government Branch Press, 1923), p. 22.

59 H. Fielding Hall, The soul of a people (London: Macmillan, 1904), p. 100. 
To assert that criminality was not an immutable state was to acknowledge the prospect that crime could be reduced, the criminal might be reformed. The same crucial point can be drawn from the British perception of the 'criminal classes'. '[T] he great majority of participants in robbery and dacoity', noted the crime enquiry committee of 1923, are members of the labouring class, the poorer classes. ${ }^{60}$ The Rangoon gaol, noted a prison administration report in the mid-1910s, held 'the large proportion of the diseased and submerged lower tenth of Rangoon's population', the vagrants, addicts, the destitute. ${ }^{61}$ But once again, these circumstances, or rather their impact in criminalising the individual, are not immutable. The vagrant can be fed, the addict broken, the dacoit disciplined. The criminal is reformed.

The prison regime in colonial Burma reflected the political imperatives and societal perceptions of its British rulers - to rework the opening sentence of this final section. The political condition was that Burma's prison was not a site of violent nationalist struggle, the social that the apparently soaring criminality of the Burmese was explained in terms of circumstance, not nature. In the first half of the 1920s, these conditions created the space for Burma's prison administration seriously to explore the reform and rehabilitation of the criminal, even to the point of questioning whether the prison - the institution of long-term imprisonment - could in fact reform. Central to that exploration was a major strengthening of the local administration's ties to international networks of prison practice and thinking, seen most strikingly in the Paterson connection.

In the 1920s, the prison administration in colonial Burma therefore found itself working within two sets of relationships, within two frameworks. The first set of relationships was with the local government, and focused on the protection of society and the punishment of the criminal, within a tight financial allocation. The second set was with the international networks of prison practice and thought, where the principal focus, by the first decades of the twentieth century at least, was on the reform and rehabilitation of the criminal. Set in one framework, Burma's senior prison administration saw reform and rehabilitation as being of critical importance, but questioned the capacity of the prison, as an institution, to secure it. The positions were radical. And they were rejected. The first framework - the local administration, and its concerns with deterrence, punishment, and cost - asserted its dominance. 